\title{
THE EFFICACY OF MALAYSIAN ONLINE SMOKING CESSATION WEBSITE BASED ON KUANTAN SMOKERS ASSESSMENT
}

\author{
Mohamad Helmy Jaafar ${ }^{1,2}$, Normalina Alias ${ }^{1,2}$ and Muhammad Lokman Md. Isa ${ }^{1,2}$. \\ ${ }^{1}$ Department Basic Medical Sciences, Kulliyyah of Nursing, \\ 2IIUM Human Molecular and Cellular Biology Research Cluster (iMoleC), International Islamic University \\ Malaysia, Jln Sultan Ahmad Shah, Bandar Indera Mahkota, 25200 Kuantan, Pahang, Malaysia.
}

Corresponding author: Muhammad Lokman Md. Isa ${ }^{1}$

Email: lokman@iium.edu.my

\begin{abstract}
Tobacco-related diseases are the leading causes of death worldwide. Tobacco use must be reduced and controlled. Due to its low cost, internet intervention has a high probability of attracting a large number of smokers, however, more research is needed to determine its most effective use. The purpose of this study was to analyze the efficacy of online smoking cessation websites in Malaysia based on assessment by Kuantan smokers. A cross-sectional study using a mix method was conducted among smokers in Kuantan, Pahang. The evaluation is divided into two phases: phase I is the selection of a website by a content expert, and phase II is the review of a selected local website by a local respondent. Random purposive sampling among 35 smokers were recruited in phase 2 . There were predetermined criteria in both phase. Website search was conducted thru identified keyword using search engine google. In phase 2, the selected good score website will be assessed by local smokers based on validated checklist. Three websites which were JomQuit.com, Nicorette.com and Quit Smoking Clinic IJN was selected for the review. The website JomQuit.com was identified as comprehensive anti-smoking website in Malaysia. The Malaysian online smoking cessation was believed to be helpful to quit smoking, provide interesting content and information, increase awareness and increase promotion. Regular website assessments must be performed on a regular basis to ensure that the information on the website is applicable to local communities and for content improvement purposes.
\end{abstract}

Keywords: Smoking cessation, Quit smoking , Stop smoking

\section{INTRODUCTION}

In many nations, smoking became a preventable cause of disease and premature death ${ }^{1}$. Around $1 \%$ of the more than 7000 chemical substances produced by burning tobacco are recognized as leading causes or reliable risk factors for smoking related diseases such as lung cancer and emphysema ${ }^{2}$. Following a steady decrease in global smoking, tobacco nevertheless kills more than 7 million people annually ${ }^{3}$. In 2015, approximately $22.8 \%$ of Malaysians were smokers, $43 \%$ of men and $1.4 \%$ of women smokers and only about $52.3 \%$ of smokers tried to stop smoking all year round ${ }^{4}$. However, Malaysia also faces challenges when it comes to reduce the prevalence of smoking.

According to the Institute of Public Health ${ }^{4}$, approximately $22.8 \%$ of Malaysians smoked, with $43 \%$ of men smoking and 1.4 percent of women smoking. The Institute for Public Health ${ }^{4}$ also discovered that only about $52.3 \%$ of smokers tried to quit smoking all year. The prevalence of smoking in Malaysia can be reduced by focusing on the high quality of smoking cessation program and encourage more smokers to join the program with the help of various parties. There are many smoking cessation programs organized by various parties including government and nongovernment organizations (NGO) aimed at helping smokers to quit smoking. However, this smoking cessation programs will never stop until the world is free of cigarettes.

There are various ways to reduce the number of smokers and help smokers quit smoking ${ }^{5}$. One of them is through online smoking cessation websites that are increasingly used around the world. For instance, more than 12 million smokers in the United States went online in 2017 to search for information on quitting smoking ${ }^{6}$. According to Keane et $\mathrm{al}^{7}$, interactive online smoking cessation programs are being enhanced by increasing Internet access and use. In comparison, the online smoking cessation intervention was significantly less expensive and better known than quitline. Online smoking cessation website services are also easy for consumers and the content is available 24 hours a day.

Globally, millions of people use websites to help them quit smoking, but effectiveness tests have an average data retention rate of $34 \%$ and an average quit rate of $9 \%^{8}$. Smoking cessation was not an easy task for the smokers. It was a difficult and complex process and smokers used various methods and strategies to achieve the goal. Simultaneously, many smokers may take 30 or more attempts to quit before they can be successful for a year or longer?.

Taylor et $\mathrm{al}^{10}$ shared that because of the low cost per user, the Internet is an appealing platform for helping people quit smoking, and it has the 
potential to reach smokers who might not access support due to limited health care availability or stigmatization. Internet-based interventions could also be used to target young smokers or others who may not seek traditional smoking cessation methods ${ }^{10}$.

According to the Internet Users Survey $2018^{11}$, there are approximately 28.7 million internet users in Malaysia, up from 24.5 million in 2016. As a result, using the internet as a smoking intervention will speed up community health promotion about the dangers of smoking. Online smoking cessation websites that were interactive and customized to individual abilities led to higher quit rates than usual treatment or written self-help at six months or longer ${ }^{10}$. Smoking cessation websites programs were a promising delivery system for assisting smokers to quit, but further research was needed to identify smokers view on the effective use of websites.

Smokers can now access a plethora of online smoking cessation websites via the Internet. At the same time, the abundance of websites makes it difficult for smokers to find the best and most effective site for references. Some websites have content that is similar to others, while others do not. The components in the websites are varies and is not standardized. Because of that, the standardization of component of the online smoking cessation websites will be effective in motivating and helping smokers to quit smoking and avoid relapse after treatment. Furthermore, no studies in Malaysia have yet examined the efficacy of online smoking cessation websites among smoker participants offered on the Internet, particularly smokers in Kuantan.

The goal of this research is to evaluate the efficacy of online smoking cessation websites among smokers in the Kuantan population by analyzing the perspectives of smokers participating in the smoking cessation program, thereby identifying important criteria needed to improve smoking cessation websites in Malaysia based on local needs. This study may assist Malaysian website developers in creating better and more effective smoking cessation websites for users who want to quit smoking by adding or improving essential elements to the websites. Analyzing and identifying the effectiveness of smoking cessation websites in Malaysia was critical for smokers participating in the program to ensure that their efforts to quit smoking are worthwhile and successful at the end of the program. Malaysian website reviews were conducted among the local respondent based on validated checklist and opinion will be gathered for improvement of the local website.

\section{METHODS}

A mix method - cross-sectional study design was conducted among smokers in Kuantan, Pahang.
The evaluation involves two phases which were phase I - website selection by content expert and phase II - review on selected local website by local respondent.

\section{Phase I - Website selection by Content Expert}

Prior to website review, there were a process selection of local website. This methodology was adapted from the study of Bock et al 9,12.

The team consists of three reviewers were assigned for the review. No reviewer had consulted for or had any financial interest or involvement with any of the Web sites they were assigned to review. Four Web sites were reviewed for training purposes. After each training review, panel members met to discuss the review process, compare outcomes, and modify the assessment forms as needed (e.g., to improve clarity of instructions, ratings procedures, and ratings criteria).

Website searches were conducted by keyword search in 'smoking cessation Malaysia', 'quit smoking Malaysia' and 'stop smoking Malaysia' as the keywords into Google.com. According to the Alexa Top 500 Global Sites, Google.com is listed as the top most visited websites in Malaysia ${ }^{13}$.The keyword based on previous study by Bock et all ${ }^{9}$, however, due to website focused in Malaysia, the word Malaysia has been combined with the keyword. All websites found within the first two pages of search results were compiled as potential sites to review. However, websites that appeared in more than one search were removed from the list.

Websites that have been found using keywords were screening by titles and all criteria of inclusion and exclusion that not meet were rejected. It is because the main concerned is smoking cessation, the websites appeared which are not related to smoking cessation is immediately rejected. Websites were excluded from analysis if they meet one or more of the following criteria (i) Product sales only (Sale product for smokers to quit smoking); (ii) Libraries sites that contain articles about smoking cessation but provide no clear guidance for the smokers who wishes to quit; (iii) Advocacy and political action sites; (iv) Site content not tobacco related; (v) Sites that contain links to other sites; (vi) Clinic and practitioners advertising face-to-face service provided; and (vii) Dead websites.

Reviews for selected final each site were conducted independently by two reviewers assigned to each web site. Any disagreement will be forwarded to third reviewer for finalization.

The review based on element 10 elements which were (i) advice to quit; (ii) access readiness to quit; (iii) assist with quit plan, (iv) provide practical counselling; (v) provide intra treatment social support; (vi) recommended use of pharmacotherapy; (vii) arrange follow-up 
therapy; (viii) enhance motivation, risk; (ix) enhance motivation, reward; and $(x)$ enhance motivation, roadblock?

The selection of website based on scoring mark as agree (7 - 10), natural (4 - 6) and disagree (0 -3). Only score "agree" will be proceeded to phase II.

The selected website will be reviewed by local participant based on validated questionnaires.

\section{Phase 2 - Review on selected local website by local respondent}

The sampling technique used was a purposive random sampling for those eligible respondents around the study setting. The respondents were recruited based of the pre-determined inclusion criteria which were smokers who stayed in Kuantan, Malaysian, age between 18 to 60 years old and able to understand either Malay or English languages and internet literate. Respondents who are not Malaysians, do not complete the questionnaire, and do not cooperate well will be excluded from this study. The sample size in this study was based on by Lancaster, Dodd, \& Williamson $^{14}$, with his rule of thumb of using a sample size of 40 or greater to estimate a parameter in order to alleviate the underpowered problem. For this study, only $20 \%$ dropout will be permitted, implying that the minimum respondent number should be no less than 32 .

The questionnaires in both language Malay and English have been reviewed and tested with Cronbach alpha 0.8. Participants were given validated questionnaires prior to the start of the session. They were informed regarding the study and written informed consent were obtained. Before the questionnaire given, the participants assessed the available online smoking cessation websites in the computer setting. A short briefing had been given to explain the purpose and objective of this study. The questionnaire consists of three parts.

Part A was the demographic data that consist of respondent's age, gender, occupation, salary, level of education, marital status and race. Part B was about questionnaire of standardized checklist for websites assessment which consist of 10 questions. The questionnaire based on 10 elements which were (i) advice to quit; (ii) access readiness to quit; (iii) assist with quit plan, (iv) provide practical counselling; (v) provide intra treatment social support; (vi) recommended use of pharmacotherapy; (vii) arrange follow-up therapy; (viii) enhance motivation, risk; (ix) enhance motivation, reward; and $(x)$ enhance motivation, roadblock ${ }^{9}$. The 10 elements will be grouped to 5 which were (i) preparation to quit (advise, access, assist); (ii) support (counselling, social support); (iii) medication; (iv) follow up; and (v) motivation (risks, rewards, roadblock). Part $C$ was about open ended question of opinion and suggestion of the website.

The questionnaires were prepared in Malay and English form by considering the language used by the respondents. Respondent also has the right to withdraw from this research at any time without reason and the respondent will be anonymous. All information and data in this study were kept private and confidential.

\section{Statistical Analysis}

The data was analysed using SPSS version 29. The descriptive analysis was used to determine the information needed to improve the most visited online smoking cessation websites in Malaysia from local smokers in form of frequency and percentage. The open-ended question at the end of the checklist was analysed based on thematic analysis related to data saturation.

\section{RESULTS}

Phase I - Website selection by Content Expert Five websites were selected after thorough screening. The assessment on selected website will be conducted and score above 7 will be accepted.

Table I: Selected online smoking cessation websites in Malaysia

\begin{tabular}{lllcc}
\hline No & Website Name & URL & Score 1 & Score 2 \\
\hline $\mathbf{1}$ & Jomquit.moh.gov.my & http://jomquit.moh.gov.my/ & 10 & 10 \\
$\mathbf{2}$ & Nicorette.com.my & https://www.nicorette.com.my/ & 10 & 10 \\
$\mathbf{3}$ & IJN Quit Smoking Clinic & $\begin{array}{l}\text { https://www.ijn.com.my/specialty-clinic/quit- } \\
\text { smoking-clinic/ } \\
\text { http://www.myhealth.gov.my/en/quit-smoking- } \\
\mathbf{p r i m e - y e a r s - 2 / ~}\end{array}$ & 7 & 7 \\
$\mathbf{5}$ & Myhealth.gov.my & Quit Smoking Clinic- NCSM & 5 & 5 \\
& clinic//cancer.org.my/get-screened/quit-smoking- & 5 & 6 \\
\hline
\end{tabular}


Phase II - Review on selected local website by local respondent

In the phase II, findings will be divided into three part which were part A - Socio-Demographic, Part B - Website assessment (quantitative) and Part C - Website assessment (qualitative -open ended questionnaire).

\section{Part A : Socio-Demographic Data Characteristics}

A total of 35 respondents had participated in this study. Majority of the respondent were from age category of 26-30 with 13 respondents (37.1\%), followed by above 30 categories with 9 respondents $(25.2 \%), 21-25$ category with 8 respondents $(22.9 \%)$ and the rest were 20 and below category with $5(14.8 \%)$. Majority of the respondent were male which was 35 respondents $(100 \%)$. In addition, most of the respondents were Degree student $(57.1 \%)$, followed by Diploma (34.3\%), SPM (5.7\%), SRP or PMR level (2.9\%) and
(0\%) participated from Primary school, STPM, Matriculation and PHD respondent. This study also found that majority of the participate respondents were Officer (42.9\%), followed by Professional (37.1\%), student (14.3\%) and unemployed (5.7\%). Majority of the respondent had salary scale RM1000-RM5000 which was 48.6 $\%$ (17 respondents), scale RM 5000 and above was 25.7\% (9 respondents), scale RM0 - RM1000 was $5.7 \%$ (2 respondents) and no monthly salary with 7 respondents (20\%). This study recognized the majority of the respondents are married with 25 respondents (71.4\%) and single with 10 respondents $(28.6 \%)$. Furthermore, most of the respondent were Malay (97.1\%), followed by others $(2.9 \%)$ and $(0 \%)$ from Chinese and Indian. All respondents were smoker (100\%). Table II shows the detailed of socio-demographic data of the respondents.

Table II: Socio-Demographic Data $(n=35)$

\begin{tabular}{|c|c|c|c|}
\hline Variables & Category & Frequency & Percentage (\%) \\
\hline \multirow[t]{4}{*}{ Age } & 20 and below & 5 & 14.3 \\
\hline & $21-25$ & 8 & 22.9 \\
\hline & $26-30$ & 13 & 37.1 \\
\hline & 30 and Above & 9 & 25.7 \\
\hline \multirow[t]{2}{*}{ Gender } & Male & 35 & 100 \\
\hline & Female & 0 & 0 \\
\hline \multirow[t]{8}{*}{ Education } & Primary school & 0 & 0 \\
\hline & SRP/PMR & 1 & 2.9 \\
\hline & SPM & 2 & 5.7 \\
\hline & STPM & 0 & 0 \\
\hline & Matriculation & 0 & 0 \\
\hline & Diploma & 12 & 34.3 \\
\hline & Degree & 20 & 57.1 \\
\hline & PHD & 0 & 0 \\
\hline \multirow[t]{4}{*}{ Occupation } & Officer & 15 & 42.9 \\
\hline & Professional/Management & 13 & 37.1 \\
\hline & Unemployed & 2 & 5.7 \\
\hline & Student & 5 & 14.3 \\
\hline \multirow[t]{4}{*}{ Salary } & RM0-RM1000 & 2 & 5.7 \\
\hline & RM1000-RM5000 & 17 & 48.6 \\
\hline & RM5000 and Above & 9 & 25.7 \\
\hline & None & 7 & 20 \\
\hline \multirow{4}{*}{ Marital Status } & Single & 10 & 28.6 \\
\hline & Married & 25 & 71.4 \\
\hline & Divorce & 0 & 0 \\
\hline & Widow & 0 & 0 \\
\hline \multirow{4}{*}{ Race } & Malay & 34 & 97.1 \\
\hline & Chinese & 0 & 0 \\
\hline & Indian & 0 & 0 \\
\hline & Others (Melanau) & 1 & 2.9 \\
\hline \multirow[t]{2}{*}{ Smoker } & Yes & 35 & 100 \\
\hline & No & 0 & 0 \\
\hline
\end{tabular}


Part B : Determining information needed to improve the most visited online smoking cessation websites in Malaysia from local smokers based on standardized checklist form.

Table III : Availability required information from local review
Table III shows availability required information or element from local respondent review.

\begin{tabular}{|c|c|c|c|c|c|}
\hline \multirow[t]{2}{*}{ No } & \multirow[t]{2}{*}{ Elements } & \multirow{2}{*}{$\begin{array}{l}\text { Category } \\
\text { Yes/No }\end{array}$} & \multicolumn{3}{|c|}{ Website } \\
\hline & & & Jomquit.moh.gov.my & Nicorette.com.my & $\begin{array}{l}\text { Quit Smoking } \\
\text { Clinic IJN }\end{array}$ \\
\hline \multirow[t]{2}{*}{1} & \multirow[t]{2}{*}{ Advice to Quit } & Yes & $32(91.4 \%)$ & $31(88.6 \%)$ & $29(82.9 \%)$ \\
\hline & & No & $3(8.6 \%)$ & $4911.4 \%)$ & $6(17.1 \%)$ \\
\hline 2 & $\begin{array}{l}\text { Assess readiness to } \\
\text { Quit }\end{array}$ & $\begin{array}{l}\text { Yes } \\
\text { No }\end{array}$ & $\begin{aligned} 32 & (91.4 \%) \\
3 & (8.6 \%)\end{aligned}$ & $\begin{array}{l}33(94.3 \%) \\
2(5.7 \%)\end{array}$ & $\begin{array}{c}29(82.9 \%) \\
6(17.1 \%)\end{array}$ \\
\hline 3 & $\begin{array}{l}\text { Assist with quit } \\
\text { plan }\end{array}$ & $\begin{array}{l}\text { Yes } \\
\text { No }\end{array}$ & $\begin{array}{c}33(94.3 \%) \\
2(5.7 \%)\end{array}$ & $\begin{array}{c}31(88.6 \%) \\
4(22.4 \%)\end{array}$ & $\begin{array}{l}29(82.9 \%) \\
6(17.1 \%)\end{array}$ \\
\hline \multirow[t]{2}{*}{4} & \multirow{2}{*}{$\begin{array}{l}\text { Provide practical } \\
\text { counselling }\end{array}$} & Yes & 27 (77.1\%) & $31(88.6 \%)$ & $28(80 \%)$ \\
\hline & & No & $8(22.9 \%)$ & $4(11.4 \%)$ & $7(20 \%)$ \\
\hline \multirow[t]{2}{*}{5} & \multirow{2}{*}{$\begin{array}{ll}\text { Provide } & \text { intra- } \\
\text { treatment } & \text { social } \\
\text { support } & \end{array}$} & Yes & $29(82.9 \%)$ & 27 (77.1\%) & 25 (71.4\%) \\
\hline & & No & $6(17.1 \%)$ & $8(22.9 \%)$ & $10(28.6 \%)$ \\
\hline \multirow[t]{2}{*}{6} & \multirow{2}{*}{$\begin{array}{l}\text { Recommended use } \\
\text { of } \\
\text { pharmacotherapy }\end{array}$} & Yes & 33 (94.3\%) & 29 (82.9\%) & $28(80 \%)$ \\
\hline & & No & $2(5.7 \%)$ & $6(17.1 \%)$ & $7(20 \%)$ \\
\hline \multirow[t]{2}{*}{7} & \multirow{2}{*}{$\begin{array}{l}\text { Arrange follow up } \\
\text { therapy }\end{array}$} & Yes & $30(85.7 \%)$ & $21(60 \%)$ & 25 (71.4\%) \\
\hline & & No & $5(14.3 \%)$ & 14 (40\%) & $10(28.6 \%)$ \\
\hline \multirow[t]{2}{*}{8} & \multirow{2}{*}{$\begin{array}{l}\text { Enhance } \\
\text { motivation; Risk }\end{array}$} & Yes & $27(77.1 \%)$ & $31(88.6 \%)$ & $30(85.7 \%)$ \\
\hline & & No & $8(22.9 \%)$ & $4(11.4 \%)$ & $5(14.3 \%)$ \\
\hline \multirow[t]{2}{*}{9} & \multirow{2}{*}{$\begin{array}{l}\text { Enhance } \\
\text { motivation; Reward }\end{array}$} & Yes & 29 (82.9\%) & 28 (80\%) & $20(57.1 \%)$ \\
\hline & & No & $6(17.1 \%)$ & 7 (20\%) & 15 (42.9\%) \\
\hline \multirow[t]{2}{*}{10} & \multirow{2}{*}{$\begin{array}{l}\text { Enhance } \\
\text { motivation; } \\
\text { Roadblock }\end{array}$} & Yes & 27 (77.1\%) & $26(74.3 \%)$ & 25 (71.4\%) \\
\hline & & No & $8(22.9 \%)$ & $9(25.7 \%)$ & $10(28.6 \%)$ \\
\hline
\end{tabular}

Table IV : Required variables to be added in the website

\begin{tabular}{|c|c|c|c|}
\hline \multirow[t]{2}{*}{ Variables } & JomQuit & Nicorette.com.my & Quit Smoking Clinic IJN \\
\hline & $\begin{array}{c}\text { Frequency } \\
\text { (Percentage \%) }\end{array}$ & $\begin{array}{c}\text { Frequency } \\
\text { (Percentage \%) }\end{array}$ & $\begin{array}{c}\text { Frequency } \\
\text { (Percentage \%) }\end{array}$ \\
\hline
\end{tabular}

\begin{tabular}{|c|c|c|c|}
\hline Provide Practical & $8(22.9 \%)$ & - & $7(20 \%)$ \\
\hline $\begin{array}{l}\text { Provide Intra-treatment } \\
\text { Social Support }\end{array}$ & - & $8(22.9 \%)$ & $10(28.6 \%)$ \\
\hline $\begin{array}{l}\text { Recommended Use of } \\
\text { Pharmacotherapy }\end{array}$ & - & & $7(20 \%)$ \\
\hline $\begin{array}{l}\text { Arrange Follow up } \\
\text { Therapy }\end{array}$ & - & $14(40 \%)$ & $10(28.6 \%)$ \\
\hline $\begin{array}{l}\text { Enhance Motivation: } \\
\text { Reward }\end{array}$ & - & 7 (20\%) & 15 (42.9\%) \\
\hline $\begin{array}{l}\text { Enhance Motivation: } \\
\text { Roadblock }\end{array}$ & $8(22.9 \%)$ & $9(25.7 \%)$ & $10(28.6 \%)$ \\
\hline Enhance Motivation: Risk & $8(22.9 \%)$ & & \\
\hline
\end{tabular}


Table IV below show the elements in the checklist that must be add in the three websites available after being assess by thirty-five respondents. Only frequency of 7 onwards will be count as element that need to add up.

Part C: Open-Ended Questions of Kuantan smoker's opinion related to the online smoking cessation websites that available in Malaysia.

There are three open-ended questionnaires in part $\mathrm{C}$ about opinions on online smoking cessation websites available in Malaysia. Table $\mathrm{V}$ shows thematic analysis - verbatim transcriptions.

Q1: Smoker's opinion regarding the online smoking cessation website based on the 3 websites given.

Respondent shared opinion about online smoking cessation website based on three website given. Four themes were developed which were "good website"; "informative"; "easy to

use/find/access"; and "useful and helpful".

Theme:

Theme I : Good website

Theme II : Informative

Theme III : Easy to use/find/access

Theme IV : Useful \& helpful

\section{Theme I: Good website}

This study found that, thirteen respondents which were respondent number $3,6,7,8,9,10$, 20,22,23,25,27, 30 and 34 illustrated the websites as good. The respondents surely think the websites is very good in giving the right way for those who have an intention to quit smoking. They also think that the quit program offered in the websites is really good and valuable.

Theme II: Informative

This study found that, eleven respondents which were respondent number

$1,5,7,9,13,17,18,21,25,29$ and 31 identified the websites as an informative tool for them to seek the knowledge about consequences of smoking and way to stop smoking effectively.

\section{Theme III : Easy to use/find/access}

This study identified that six respondents which were respondent number 1,4,15,16,21 and 27 found the websites as an easy to use or find or access at any time. The respondents can found the websites easily in the internet and information given in the websites was very easy for them to understand.

Theme IV: Useful and helpful.

This study found that, twelve respondents which were respondent number $1,4,8,11,12,21,25,26,29,32,33$ and 35 pointed out that the websites was useful and helpful in guiding smokers to quit smoking effectively.
Q2 : Smoker's ideas which they like to suggest in improving the quality of online smoking cessation website based on the 3 websites given.

Respondents illustrated their idea in improving the quality of smoking cessation website based on the websites given. Two themes were developed for Q2 which were "improve content" and "boost advertisement and promotion".

Theme:

Theme V: Improve content

Theme VI: Boost advertisement and promotion

\section{Theme V: Improve content}

This study found that, fifteen respondents which were respondent number $1,2,4,5,13,15,16,18,20,21,25,26.27,30,31$ and 34 expressed the idea to improve the content in the websites. The websites developer must put more effort in creating more interesting content such as put appropriate picture, add successful quit stories, videos, feedback from users, correct navigation, bilingual languages, minimal writing and put consequences of smoking.

Theme Vl: Boosts advertisement \& promotion. This study found that, five respondents which were respondent number 5,7,17,28, and 29 expressed the idea to boost ads and promotion of the websites to public widely. Wide range advertisement and promotion of the smoking cessation websites through social media will grab more attention from public especially smokers to visit the websites.

Q3: Smoker's hope for smoking cessation website in Malaysia in helping smoker to quit smoking?'

In this Q3, the respondents expressed their hope for smoking cessation website in helping smoker to quit smoking. Four themes were developed for Q3 which were helpful to quit smoking; provide interesting content and correct info; smoker aware, use and visit the website; and increase ads and promotion.

Theme:

Theme VII : Helpful to quit smoking

Theme VIII: Provide interesting content \& correct info.

Theme IX: Smoker aware, use \& visit the website. Theme $X$ : Increase ads \& promote.

Theme VII: Helpful to quit smoking.

Almost half of the respondents expressed the hope as websites was very helpful to quit smoking. The respondent which were respondent number $3,5,7,8,9,11,13,14,28,29,30,31,32$ and 19 believed that the websites would help smoker to stop smoking and maintaining their healthy life style by accessing the websites just through smartphone. 
Theme VIII: Smoker aware, use and visit the website.

Under Theme VIII, six respondents which were respondent number $6,7,10,17,29$, and 35 expressed the hope as smoker should become more aware, use and visit the smoking cessation website available in Malaysia. Smoker should take the advantages of the websites by visiting or accessing the websites in order to help them quit smoking efficiently.

Theme IX: Increase ads \& promote.

This study found that, four respondents which were respondent number $1,16,29$ and 33 expressed their hope as the website will be increasingly promoted and advertised into social media. Social media play an important rule to spread the websites widely to the public and grab more attention from smoker to join the quit smoking program offered in the websites.

\section{Theme $\mathrm{X}$ : Provide interesting content and} correct info.

This study found that, six respondents which were respondent number 21,24,25,26,27, and 34 identified their hope that the website will be featured more interesting content and providing correct information regarding the smoking and quit program. The respondent believed that interesting content in the websites will attract more attention from smoker to visit the website and join the quit smoking program.

\section{DISCUSSIONS}

Based on the checklist's 10 elements, the elements will be grouped into 5 categories based on their stages. The five groups elements were (i) preparation to quit (Advise, Assess, Assist), (ii) support (counselling, social support), (iii) medication, (iv) follow up, and (v) motivation (Risks, Rewards, Roadblock).

In terms of quitting preparation, the website jomQuit.com received the highest percentage of respondents who agreed that the website advised smokers to quit smoking. In addition, when compared to other websites, JomQuit.com encourages internet users to quit smoking by displaying words like "quit smoking now and you will be healthier" on the front page of the website. However, the highest respondent agreed to the websites that assess readiness to quit smoking were Nicorette.com. This is because of Nicorette.com highlights smart ideas by placing an option button that says "get ready to quit" at the top of the website and a series of questions and answer will come out compared to other websites. Following that, the results revealed that JomQuit.com received the highest level of support from respondents when it came to websites that help people quit smoking, followed by Nicorette.com and Quit Smoking Clinic IJN. On the front page of their website, JomQuit.com made it very clear how to quit smoking.
The next stage was support session that consists of practical counselling and intra-treatment social support. The results showed that Nicorette.com had the highest number of respondents who agreed with the websites that provided practical counselling. In comparison to other websites, Nicorette.com provides a very clear strategy for dealing with cravings during the quit process. Surprisingly, the majority of respondents agreed that jomQuit.com was the best website for intra-treatment social support. Website JomQuit.com provides an info line call number as well as attachments to social media platforms such as Twitter and Messenger. The significance of existence support sessions is consistent with previous research that Wood \& Smith ${ }^{15}$ believed that virtual support groups and counselling, which can be accessed through computer-mediated communications, have several advantages over face-to-face support groups.

In the third stage, medication use of approved pharmacotherapy is required, as is the arrangement of follow-up contact. According to the findings, the website with the highest number of respondents who agreed to the use of pharmacotherapy was JomQuit.com. In practice, JomQuit.com provided Nicotine Replacement Therapy (NRT) to help smoker quit smoking that can increase chance of success as clearly compared to other websites. In relation with that, highest number of respondents agreed to the website that provide arrangement of follow up were JomQuit.com. In comparison to other websites, JomQuit.com provides an info-line call and also encourages smokers to do online registration for further treatment or a quit plan. Bock et $\mathrm{al}^{9}$ stated that internet treatment should, at the very least, be responsive to changes in guidelines, treatment practice, known side effects, available medication, and other aspects of treatment that change over time.

In terms of follow-up, frequent follow-up is an essential component of tobacco addiction treatment. Most respondent agreed that Jomquit.moh.my provides essential component for follow-up.

In ensuring the sustainability of quit smoking, the important stage was motivation which consisting of enhance motivation of risk, enhance motivation of reward and enhance motivation of roadblock. The result showed the highest number of respondents agreed to the websites that provide motivation of risk was Nicorette.com. This is due to Nicorette.com provide an information about risk of smoking in the most interesting way and precise as compared to other website. Furthermore, the highest number of respondents agreed to the websites that provide motivation of reward was jomQuit.com because, when compared to other websites, JomQuit.com provides information regarding the benefits of 
quitting smoking in a very interesting way by putting a few pictures and description. Lastly, the result showed the highest number of respondents agreed to the website that enhance motivation of roadblock were JomQuit.com. This is because, in comparison to other websites, JomQuit.com lists a few barriers that may occur during the quit phase, along with solutions, in very interesting and clear information.

Thematic analysis was conducted for part C: Open Ended questions. In question 1 , smokers provide positive opinion towards selected three websites which were good website; informative; easy to use/find/access; and useful. This finding support info from Bock et $\mathrm{al}^{9}$ that difficult websites may lose $40 \%$ of visitors who will not return. The ability to easily use and navigate internet sites is critical to the site's success 9 . Therefore, the website providers need to ensure the website in the good performances.

Findings from Bock et $\mathrm{al}^{9}$ also indicated that majority of reviewed websites provide coverage for most key content areas identified as the core of smoking cessation treatment. This finding correlates with our smokers answer for question no 2. Respondents suggested website developer to be more creative in ensuring the content is more attractive for viewers. The respondents also suggested to use online platform for health promotion especially for smoking cessation campaign. A website need to have effective navigation as the ability to easily use and navigate internet sites is crucial to the successful use of the sites. Garret et $\mathrm{al}^{16}$ mentioned that effective navigation is when the websites have consistent menu and navigation bars, search features and easy access to pages. If a website eases the user with effective navigation, users are likely to return for repeat visits thus enhance their willingness to stop smoking. In contrast, websites that are difficult to use can result in treatment failure if users cannot find the useful information to stop smoking.

According to a previous study by Spool ${ }^{17}, 60 \%$ of the time, people cannot find the information they seek on a website. This resulted in lost time, increased frustration, and a failure to provide effective treatment. Website features that discourage repeat visits are a significant impediment to effective treatment. Similarly, if a website is simple to use and has useful and interesting features, users are more likely to return for additional visits, which may increase their chances of quitting smoking. The previous study also supported Garett et $\mathrm{al}^{16}$ findings that in order to attract repeat visitors, websites must provide quality and up-to-date information. Previous findings are consistent with our current respondent expectation. Respondents hope that the smoking cessation website in Malaysia is helpful; that it provides accurate and interesting content; that smokers are aware of its existence; and that it is more widely advertised and promoted on social media. According Cutrona SL et $\mathrm{al}^{18}$, online intervention provides benefits but underused. Therefore, thru active promotion, online intervention will reach and benefited to large communities.

This study revealed that there were numerous opportunities to conduct a survey on how smokers evaluate Malaysian online smoking cessation websites. It was suggested that we conduct research on the efficacy of Malaysian online smoking cessation websites among Malaysian smokers periodically so that we can make improvements from time to time. The study's strength was that research on the efficacy of Malaysian online smoking cessation websites was very rare among Malaysians. The accuracy of the efficacy of Malaysian online smoking cessation websites can be measured using this study. There were several limitations to the study, which were limited by the data collection setting. This study was only carried out in one specific area of Kuantan. As a result, it may be inappropriate to generalize the findings as a whole for Kuantan. The second limitation was that it was difficult to approach smokers to participate in this study because they discovered that quitting smoking is a sensitive topic to discuss. The third limitation was the lack of previous research for further discussion and data comparison on the findings. The majority of researchers choose smoking as their research topic, but fewer do research on the effectiveness of Malaysian online smoking cessation websites.

\section{CONCLUSIONS}

According to a standardized checklist of online smoking cessation websites assessed by Kuantan smokers, JomQuit.com had the highest efficacy of Malaysian online smoking cessation websites, followed by Nicorette.com, and the lowest quality was Quit Smoking Clinic IJN. The checklist can be used by website providers to ensure that an effective and comprehensive website is created.

The Malaysian online smoking cessation websites were found to be good, informative, easy to use, and useful for quitting smoking in this study. The study also revealed that Malaysian online smoking cessation websites need to improve their content as well as increase their advertising and promotion across the country. The Malaysian online smoking cessation was believed to be helpful to quit smoking, provide interesting content and information, increase awareness and increase promotion. Regular website assessment shall be reviewed periodically in order to ensure the information in the website relevant to apply for local communities and for content improvement purposes. 


\section{ACKNOWLEDGEMENT}

The author would like to thank all team members who have contributed to this article.

\section{Conflict of interest}

The authors have no conflict of interest to declare with regard to this work.

\section{Competing interests}

The authors declare that they have no competing interests

\section{REFERENCE}

1. Pourtau L, Martin E, Menvielle G et al. To smoke or not to smoke? A qualitative study among young adults [published correction appears in Prev Med Rep. $2020 \quad$ Dec 12;20:101284]. Prev Med Rep. 2019;15:100927. Published 2019 Jun 22.

doi:10.1016/j.pmedr.2019.100927

2. Rahman B , Naile G, Benay CE. An Overview of $\mathrm{iQOS} \otimes$ as a New HeatNot-Burn Tobacco Product and Its Potential Effects on Human Health and the Environment. Turk J Pham Sci. 2019. $16 . \quad 371-374$. 10.4274/tjps.galenos.2018.79095.

3. WHO. WHO global report on trends in prevalence of tobacco smoking 20002025 (2018), Retrieved from https: / /www.who.int/tobacco/publi cations/surveillance/trends-tobaccosmoking-second-edition/en/

[Accessed May 21, 2019]

4. Institute for Public Health. National Health and Morbidity Survey - Report on Smoking Status Among Malaysian Adults 2015 . Ministry of Health Malaysia [Retrieved from https://www.moh.gov.my/moh/reso urces/NHMS2015-VolumeV.pdf]

[Accessed Jun 7,2019]

5. WHO. WHO report on the global tobacco epidemic, 2019: offer help to quit tobacco use: executive summary (2019) Retrieved at : https://www. who.int/teams/healthpromotion/tobacco-control/whoreport-on-the-global-tobaccoepidemic-2019 [Accessed July 25, 2019]

6. Graham AL, Amato MS. Twelve Million Smokers Look Online for Smoking Cessation Help Annually: Health Information National Trends Survey Data, 2005-2017. Nicotine Tob Res. 2019 Jan 4;21(2):249-252. doi: 10.1093/ntr/nty043. PMID: 29660037; PMCID: PMC6319446.

7. Keane L., Anderson C., Perez D., et al. The Development and Evaluation of Online Smoking Cessation Services : A Narrative Literature Review. Journal of Smoking Cessation (September 2018). https://doi.org/10.1017/jsc.2018.8

8. Chaiton M., Diemert L., Cohen JE., et al. Estimating the number of quit attempts it takes to quit smoking successfully in a longitudinal cohort of smokers. BMJ Open 2016 https://doi.org/10.1136/bmjopen2016-011045

9. Bock B, Graham A, Sciamanna C, et al. Smoking cessation treatment on the Internet: content, quality, and usability. Nicotine Tob Res. 2004 Apr;6(2):207-19. doi: $10.1080 / 14622200410001676332$. PMID: 15203794.

10. Taylor GMJ, Dalili MN, Semwal M et al. Internet-based interventions for smoking cessation. Cochrane Database Syst Rev. 2017;9(9):CD007078. Published 2017 Sep 4. doi:10.1002/14651858.CD007078.pub 5

11. MCMC. Internet User Survey 2018. Malaysia. Malaysian Communication \& Multimedia Commission 2018. Retrieved from https://www.mcmc.gov.my/skmmgo vmy/media/General/pdf/InternetUsers-Survey-2018.pdf [Accessed October 19,2020]

12. Bock BC, Graham AL, Whiteley JA, Stoddard JL. A review of web-assisted tobacco interventions (WATIs). J Med Internet Res. 2008 Nov 6;10(5): e39. doi: $\quad 10.2196 /$ jmir.989. PMID: 19000979; PMCID: PMC2630838

13. Alexa.com . The top 500 sites on the web [Accessed November 20, 2020]

14. Lancaster GA, Dodd S., \& Williamson PR. Design and analysis of pilot studies: Recommendations for good practice. J Eval Clin Pract.2004, 10(2), 307-312. https://doi.org/10.1111/j..2002.384 .doc.x

15. Wood AF \& Smith MJ. Seeking on-line therapy In Online communication: 
Linking technology, identity and culture. Mahwah, NJ:Lawrence Erlbaum 2001:92-108

16. Garett R, Chiu J, Zhang L, Young SD. A Literature Review: Website Design and User Engagement. Online J Commun Media Technol. 2016;6(3):114.

17. Spool, Jared M. Web Site Usability: A Designer's Guide. San Francisco, Calif: Kaufmann, 1999. Print.
18. Cutrona SL, Sadasivam RS, DeLaughter $\mathrm{K}$, et al. Online tobacco websites and online communities-who uses them and do users quit smoking? The quit-primo and national dental practice-based research network $\mathrm{Hi}$ Quit studies. Transl Behav Med. 2016;6(4):546-557. doi:10.1007/s13142-015-0373-5 
Malaysian Journal of Public Health Medicine 2021, Vol. 21 (2): 199-217

\section{Table V shows thematic analysis - verbatim}

\begin{tabular}{|c|c|c|c|c|c|c|c|c|c|c|}
\hline \multirow{2}{*}{$\begin{array}{l}\text { Question } \\
\text { Respondent }\end{array}$} & \multicolumn{4}{|c|}{$\overline{\text { Q1 }}$} & \multicolumn{2}{|c|}{ Q2 } & \multicolumn{4}{|c|}{$\overline{Q 3}$} \\
\hline & $\begin{array}{l}\text { Theme I: } \\
\text { Good } \\
\text { website }\end{array}$ & $\begin{array}{l}\text { Theme II: } \\
\text { Informative }\end{array}$ & $\begin{array}{l}\text { Theme III : Easy } \\
\text { to } \\
\text { use/find/access }\end{array}$ & $\begin{array}{l}\text { Theme IV : Useful } \\
\text { \& helpful }\end{array}$ & $\begin{array}{l}\text { Theme V : Improve } \\
\text { content }\end{array}$ & $\begin{array}{l}\text { Theme } \mathrm{VI} \text { : Boost } \\
\text { advertisement and } \\
\text { promotion }\end{array}$ & $\begin{array}{l}\text { Theme VII : } \\
\text { Helpful to } \\
\text { quit smoking }\end{array}$ & $\begin{array}{l}\text { Theme VIII : } \\
\text { Smoker } \\
\text { aware, use \& } \\
\text { visit the } \\
\text { website. }\end{array}$ & $\begin{array}{l}\text { Theme IX: } \\
\text { Increase ads \& } \\
\text { promote }\end{array}$ & $\begin{array}{l}\text { Theme X: } \\
\text { Provide } \\
\text { interesting } \\
\text { content } \& \\
\text { correct info. }\end{array}$ \\
\hline 1 & & $\begin{array}{l}\text { Lots of } \\
\text { useful info } \\
\text { given to } \\
\text { anyone who } \\
\text { browses the } \\
\text { site such as } \\
\text { expenses } \\
\text { used to buy } \\
\text { cigarettes, } \\
\text { the effects } \\
\text { of smoking } \\
\text { and the } \\
\text { benefits of } \\
\text { quitting } \\
\text { smoking. }\end{array}$ & $\begin{array}{l}\text { The website is } \\
\text { easy to use and } \\
\text { easy to access. }\end{array}$ & $\begin{array}{l}\text { Lots of useful info } \\
\text { given to anyone } \\
\text { who browses the } \\
\text { site such as } \\
\text { expenses used to } \\
\text { buy cigarettes, the } \\
\text { effects of smoking } \\
\text { and the benefits of } \\
\text { quitting smoking. }\end{array}$ & $\begin{array}{l}\text { Use more pictures or } \\
\text { drawings that can } \\
\text { interest the reader. } \\
\text { Use sentences that } \\
\text { are easy to } \\
\text { understand. Do not } \\
\text { use sentences that } \\
\text { are as long as the } \\
\text { third website. }\end{array}$ & - & - & - & $\begin{array}{l}\text { Promoting more } \\
\text { websites to more } \\
\text { people is like } \\
\text { spreading them } \\
\text { on social media. }\end{array}$ & \\
\hline 2 & - & - & - & - & $\begin{array}{l}\text { Organize the website } \\
\text { in a more orderly } \\
\text { manner and put up } \\
\text { more stories } \\
\text { regarding a smoker } \\
\text { that actually quits. }\end{array}$ & - & - & - & - & - \\
\hline 3 & $\begin{array}{l}\text { Good and } \\
\text { valuable. }\end{array}$ & - & - & - & - & - & $\begin{array}{l}\text { Will help } \\
\text { smokers to } \\
\text { stop from } \\
\text { smoking and } \\
\text { maintain } \\
\text { healthy } \\
\text { lifestyle. }\end{array}$ & - & - & - \\
\hline
\end{tabular}


It's very easy to

understand.

The website
is very
informative
to quit
smoking.
The website is very Bilingual use. I

useful for smokers believe that most of

who want to quit the program

smoking. It's very participants are

easy to use and seniors who may

easy to

understand.

have difficulty

understanding the

questions being

organized.
The website
provided is

very good

because it

provides a

platform for

smokers to

quit

smoking.

7 The 2 nd and

the 3rd web

is quite good

because

they give

enough

information

program and

program
smoking.
The 2nd and

the 3 rd web

is quite good

because

they give

enough

information

about their

program and

smoking.
Include social share

and follow buttons,

Implement calls-to-

action, Use the right

images, Navigation

must be correct, Use

some money to

promote in

advertisement page.

clude social

share and follow

buttons,

ncrease

successful

rate of

smoker that

to-action, Use the quit

right images, smoking.

Navigation must be

orrect, Use some

money to promote

in advertisement

page.

So that this

website is

known by all

Malaysians.

The website needs

to advertise

This will

help the

efficiently to

programs

be able

attract people and

aware them that

reach the

people who

counselling or join

the program. hope people

aware more

existence of

the website. 
Malaysian Journal of Public Health Medicine 2021, Vol. 21 (2): 199-217

\begin{tabular}{|c|c|c|c|c|c|c|c|c|c|c|}
\hline 8 & $\begin{array}{l}\text { Very good. } \\
\text { Help } \\
\text { smokers to } \\
\text { stop } \\
\text { smoking. }\end{array}$ & - & - & $\begin{array}{l}\text { Help smokers to } \\
\text { stop smoking }\end{array}$ & - & - & $\begin{array}{l}\text { Can help } \\
\text { smokers to } \\
\text { stop smoking } \\
\text { for good and } \\
\text { consistently. }\end{array}$ & - & - & - \\
\hline 9 & $\begin{array}{l}\text { It provide a } \\
\text { good } \\
\text { information } \\
\text { about how } \\
\text { to quit } \\
\text { smoking }\end{array}$ & $\begin{array}{l}\text { It provide a } \\
\text { good } \\
\text { information } \\
\text { about how } \\
\text { to quit } \\
\text { smoking }\end{array}$ & - & - & - & - & $\begin{array}{l}\text { I hope that } \\
\text { this website } \\
\text { will help a } \\
\text { lot more } \\
\text { smoker in } \\
\text { quitting } \\
\text { smoking }\end{array}$ & - & - & - \\
\hline 10 & $\begin{array}{l}\text { A good move } \\
\text { for smokers } \\
\text { in the age of } \\
\text { technology } \\
\text { and the } \\
\text { internet, to } \\
\text { easily } \\
\text { browse the } \\
\text { coverage of } \\
\text { smoking } \\
\text { cessation } \\
\text { websites. } \\
\text { Only } \\
\text { smokers who } \\
\text { browse the } \\
\text { website to } \\
\text { stop smoking } \\
\text { must be } \\
\text { honest, } \\
\text { sincere and } \\
\text { sincere. }\end{array}$ & - & - & - & - & - & & $\begin{array}{l}\text { It is hoped } \\
\text { that the } \\
\text { smoking } \\
\text { cessation } \\
\text { website can } \\
\text { provide } \\
\text { awareness on } \\
\text { the benefits } \\
\text { of quitting } \\
\text { smoking and } \\
\text { the } \\
\text { disadvantages } \\
\text { of continuing } \\
\text { to smoke for } \\
\text { smokers } \\
\text { throughout } \\
\text { Malaysia. }\end{array}$ & & - \\
\hline 11 & - & - & - & $\begin{array}{l}\text { The content is } \\
\text { great, the help } \\
\text { about to be giver } \\
\text { were excellent and } \\
\text { i might consider } \\
\text { quitting with such } \\
\text { helps. }\end{array}$ & & & $\begin{array}{l}\text { Keep your } \\
\text { good work. } \\
\text { Keep helping } \\
\text { people. Keep } \\
\text { educate. } \\
\text { Dont stop }\end{array}$ & - & - & - \\
\hline 12 & - & - & - & $\begin{array}{l}\text { Very useful, } \\
\text { beneficial }\end{array}$ & - & - & - & - & - & - \\
\hline
\end{tabular}


Malaysian Journal of Public Health Medicine 2021, Vol. 21 (2): 199-217

\begin{tabular}{|c|c|c|c|c|c|c|c|c|c|c|}
\hline 13 & - & $\begin{array}{l}\text { They provide } \\
\text { complete } \\
\text { and concise } \\
\text { information } \\
\text { about how } \\
\text { to quit } \\
\text { smoking and } \\
\text { the risk of } \\
\text { smoking. }\end{array}$ & - & - & $\begin{array}{l}\text { Provide video } \\
\text { presentation instead } \\
\text { of text writing, } \\
\text { include professional } \\
\text { advices and tips } \\
\text { regarding the way to } \\
\text { stop smoking. }\end{array}$ & - & $\begin{array}{l}\text { I hope they } \\
\text { can help } \\
\text { more and } \\
\text { more } \\
\text { smokers out } \\
\text { there to quit } \\
\text { smoking and } \\
\text { an } \\
\text { organization } \\
\text { and initiative } \\
\text { must be } \\
\text { created to } \\
\text { promote } \\
\text { these } \\
\text { websites to } \\
\text { the smokers } \\
\text { who don't } \\
\text { know the } \\
\text { existence of } \\
\text { these } \\
\text { websites to } \\
\text { save } \\
\text { smokers' } \\
\text { life. }\end{array}$ & - & - & - \\
\hline 14 & & & & & & & Really help. & - & - & - \\
\hline 15 & - & - & $\begin{array}{l}\text { From my point of } \\
\text { view, the } \\
\text { platform that } \\
\text { have been } \\
\text { provided for the } \\
\text { smokers to quit } \\
\text { can easily be } \\
\text { found in the } \\
\text { internet, } \\
\text { brochures or in } \\
\text { the media social }\end{array}$ & - & $\begin{array}{l}\text { A more friendlier } \\
\text { approach in the } \\
\text { clinic via face-to- } \\
\text { face with the } \\
\text { smokers that have } \\
\text { high awareness and } \\
\text { spirit to quit is much } \\
\text { more effective. }\end{array}$ & - & & & & \\
\hline
\end{tabular}


16

$\begin{array}{ll}- & \text { Secondly, I find } \\ \text { that the template } \\ \text { for Nicorette are } \\ \text { quite pleasing } \\ \text { and easy to } \\ \text { navigate through. }\end{array}$

17

18

\section{In my}

opinion, the

site has

delivered

very concise

and concise

info.

Provide an easy

tracking-like apps??

for user to easily key

in their

achievement/improv

ement for the day to

keep them on track

and motivated.

$-$

$-$

platform

available such as

social media to

have a more

wide range

target as

websites are

rarely visited by

people

May add feedback

from people who

have stopped

smoking from the

site. For two to

three examples of

lifestyle people who

quit smoking.

More

advertisements

about the websites
I hope they

get more

recognition

from people,

especially

from them

who is using

vapes and

other

alternatives

without

consulting

anyone to quit

smoking.

Make a video 


\begin{tabular}{|c|c|c|c|c|c|c|c|c|c|c|}
\hline 21 & - & $\begin{array}{l}\text { Full of } \\
\text { information } \\
\text { that is easy } \\
\text { to } \\
\text { understand } \\
\text { and can help } \\
\text { smokers to } \\
\text { quit smoking }\end{array}$ & $\begin{array}{l}\text { Full of } \\
\text { information that } \\
\text { is easy to } \\
\text { understand and } \\
\text { can help smokers } \\
\text { to quit smoking }\end{array}$ & $\begin{array}{l}\text { Full of information } \\
\text { that is easy to } \\
\text { understand and } \\
\text { can help smokers } \\
\text { to quit smoking }\end{array}$ & $\begin{array}{l}\text { Add more pictures to } \\
\text { help readers } \\
\text { understand and get a } \\
\text { sense of what is } \\
\text { being discussed. }\end{array}$ & - & - & - & - & $\begin{array}{l}\text { My hope is } \\
\text { that smokers } \\
\text { in Malaysia } \\
\text { get the right } \\
\text { information } \\
\text { about } \\
\text { cigarette use } \\
\text { and be able } \\
\text { to choose the } \\
\text { right decision } \\
\text { to quit } \\
\text { smoking. }\end{array}$ \\
\hline 22 & Good. & - & - & - & - & - & - & - & - & - \\
\hline 23 & $\begin{array}{l}\text { Website is } \\
\text { very good. }\end{array}$ & - & - & - & - & - & - & - & - & - \\
\hline 24 & - & - & - & - & - & - & - & - & - & $\begin{array}{l}\text { Maintain the } \\
\text { website with } \\
\text { good enough } \\
\text { research and } \\
\text { development. }\end{array}$ \\
\hline 25 & $\begin{array}{l}\text { Good } \\
\text { website. } \\
\text { Provide } \\
\text { enough } \\
\text { information, } \\
\text { useful tips } \\
\text { and advices } \\
\text { provided by } \\
\text { them. }\end{array}$ & $\begin{array}{l}\text { Good } \\
\text { website. } \\
\text { Provide } \\
\text { enough } \\
\text { information, } \\
\text { useful tips } \\
\text { and advices } \\
\text { provided by } \\
\text { them. }\end{array}$ & - & $\begin{array}{l}\text { Provide enough } \\
\text { information, useful } \\
\text { tips and advices } \\
\text { provided by them. }\end{array}$ & $\begin{array}{l}\text { Add more } \\
\text { consequences of } \\
\text { smoking so that } \\
\text { people will be afraid } \\
\text { to smoke. }\end{array}$ & - & - & - & - & $\begin{array}{l}\text { Provide more } \\
\text { information } \\
\text { about the } \\
\text { smoking, how } \\
\text { to stop, } \\
\text { where to seek } \\
\text { help etc. }\end{array}$ \\
\hline 26 & - & - & - & $\begin{array}{l}\text { Very helpful and } \\
\text { user friendly. }\end{array}$ & $\begin{array}{l}\text { Put some videos } \\
\text { regarding bad effect } \\
\text { of smoking or else. } \\
\text { Sometimes people } \\
\text { tend to hear and } \\
\text { look than read. }\end{array}$ & - & - & - & - & $\begin{array}{l}\text { Hopefully, } \\
\text { this kind of } \\
\text { website will } \\
\text { keep } \\
\text { improving on } \\
\text { their contents } \\
\text { and could } \\
\text { inspire others } \\
\text { to quit } \\
\text { smoking. }\end{array}$ \\
\hline
\end{tabular}




\begin{tabular}{|c|c|c|c|c|c|c|c|c|c|c|}
\hline 27 & $\begin{array}{l}\text { Good. } \\
\text { Enough } \\
\text { information } \\
\text { and advices } \\
\text { provided by } \\
\text { them. Got } \\
\text { some useful } \\
\text { tips too. } \\
\text { Thank you } \\
\text { very much. }\end{array}$ & - & $\begin{array}{l}\text { Good. Enough } \\
\text { information and } \\
\text { advices provided } \\
\text { by them. Got } \\
\text { some useful tips } \\
\text { too. Thank you } \\
\text { very much }\end{array}$ & - & $\begin{array}{l}\text { Put consequences of } \\
\text { smoking so that } \\
\text { people will be afraid } \\
\text { to smoke again. Add } \\
\text { more pictures to get } \\
\text { people attentions }\end{array}$ & - & - & - & - & $\begin{array}{l}\text { Give more } \\
\text { information } \\
\text { about the } \\
\text { smoking and } \\
\text { how to stop } \\
\text { and where to } \\
\text { seek help. }\end{array}$ \\
\hline 28 & - & - & - & - & - & $\begin{array}{l}\text { Always promote to } \\
\text { the public, } \\
\text { because many still } \\
\text { do not know about } \\
\text { this. }\end{array}$ & $\begin{array}{l}\text { To continue } \\
\text { this (develop } \\
\text { more } \\
\text { websites) to } \\
\text { encourage } \\
\text { smokers to } \\
\text { quit } \\
\text { smoking. }\end{array}$ & - & - & - \\
\hline 29 & - & $\begin{array}{l}\text { Lots of } \\
\text { useful info } \\
\text { given to } \\
\text { anyone who } \\
\text { browses the } \\
\text { site such as } \\
\text { expenses } \\
\text { used to buy } \\
\text { cigarettes, } \\
\text { the effects } \\
\text { of smoking } \\
\text { and the } \\
\text { benefits of } \\
\text { quitting } \\
\text { smoking. }\end{array}$ & - & $\begin{array}{l}\text { Smoking cessation } \\
\text { websites are very } \\
\text { helpful for hard } \\
\text { core smokers to } \\
\text { start quitting. }\end{array}$ & (1) & $\begin{array}{l}\text { Among the } \\
\text { suggestions I think } \\
\text { is that such } \\
\text { websites need } \\
\text { more attention in } \\
\text { terms of } \\
\text { advertising and } \\
\text { promotion. }\end{array}$ & $\begin{array}{l}\text { I hope that } \\
\text { this kind of } \\
\text { website can } \\
\text { help young } \\
\text { people to } \\
\text { quit smoking } \\
\text { nowadays } \\
\text { because } \\
\text { young people } \\
\text { are more } \\
\text { comfortable } \\
\text { with their } \\
\text { smartphones } \\
\text { and it is not } \\
\text { wrong for } \\
\text { them to take } \\
\text { the time to } \\
\text { access such } \\
\text { websites for } \\
\text { themselves. }\end{array}$ & $\begin{array}{l}\text { I also hope } \\
\text { that this } \\
\text { website can } \\
\text { strive to get } \\
\text { more visitors } \\
\text { from smokers } \\
\text { in Malaysia by } \\
\text { doing more } \\
\text { ads and } \\
\text { promotions. }\end{array}$ & $\begin{array}{l}\text { I also hope that } \\
\text { this website can } \\
\text { strive to get } \\
\text { more visitors } \\
\text { from smokers in } \\
\text { Malaysia by doing } \\
\text { more ads and } \\
\text { promotions. }\end{array}$ & - \\
\hline 30 & $\begin{array}{l}\text { Good } \\
\text { initiatives to } \\
\text { give a } \\
\text { chance for } \\
\text { the smokers } \\
\text { to quit } \\
\text { smoking by } \\
\text { giving } \\
\text { various }\end{array}$ & - & - & - & $\begin{array}{l}\text { If possible, try not to } \\
\text { use the damaged } \\
\text { health pictures like } \\
\text { lung cancers and } \\
\text { abnormal new-born } \\
\text { because it is too } \\
\text { common and some of } \\
\text { the smokers really } \\
\text { do not care. Instead, }\end{array}$ & - & $\begin{array}{l}\text { I'm hoping } \\
\text { that the } \\
\text { websites will } \\
\text { no matter to } \\
\text { continuously } \\
\text { support the } \\
\text { effort of the } \\
\text { smokers to } \\
\text { quit. }\end{array}$ & - & - & - \\
\hline
\end{tabular}




\author{
For me, the \\ second \\ website is \\ the best as \\ it is simple \\ but the \\ information \\ needed are$$
\text { there. }
$$

It is very

convenient and helpful for the smokers.

This website is very helpful for hard-core smokers

to stop smoking

user-friendly

funds.

$\begin{array}{ll}\begin{array}{ll}\text { Make it simple, less } \\ \text { wordy with good }\end{array} & \text { There should } \\ \text { design to attract } & \text { be more } \\ \text { people to read more } & \text { websites to } \\ \text { and give morale for } & \text { help the } \\ \text { the smoker to stop } & \text { smoker } \\ \text { smoking. } & \text { which can } \\ & \text { make it } \\ & \text { easier for } \\ & \text { them to seek } \\ & \text { for the help } \\ & \text { when they } \\ & \text { wanted to } \\ & \text { stop } \\ & \text { smoking. } \\ & \text { To help the } \\ & \text { smokers with } \\ & \text { a healthy } \\ \text { - } & \text { lifestyles. } \\ & -\end{array}$

Stop smoking websites must always promoting this program into social media.
Provide video that

related with

dangerous of

smoking.
My hope is we must do something to attract smoker to stop smoking like providing something more

interesting and easy to grab public 
Malaysian Journal of Public Health Medicine 2021, Vol. 21 (2): 199-217

websites is really

useful because it is

as a support to be

closed with smoker

in website

relationship or

social.

I hope mor

people is

going to use

the websites

and product

to quit

smoking. 